This article was downloaded by: [University of Sydney]

On: 04 May 2015, At: 17:48

Publisher: Routledge

Informa Ltd Registered in England and Wales Registered Number: 1072954

Registered office: Mortimer House, 37-41 Mortimer Street, London W1T

3J H, UK

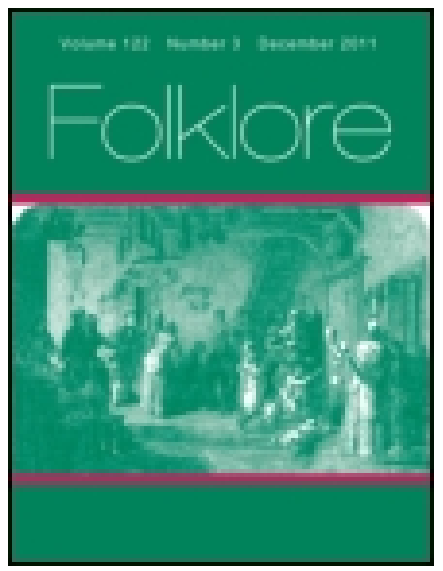

\title{
Folklore
}

Publication details, including instructions for authors and subscription information:

http:// www. tandfonline.com/loi/ rfol20

\section{Dr. Howitt's Defence Of Groupmarriage}

N. W. Thomas

Published online: 14 Feb 2012.

To cite this article: N. W. Thomas (1906) Dr. Howitt's Defence Of Groupmarriage, Folklore, 17:3, 294-307, DOI: 10.1080/ 0015587X. 1906.9719739

To link to this article: http:// dx.doi.org/ 10.1080/ 0015587X. 1906.9719739

\section{PLEASE SCROLL DOWN FOR ARTICLE}

Taylor \& Francis makes every effort to ensure the accuracy of all the information (the "Content") contained in the publications on our platform. However, Taylor \& Francis, our agents, and our licensors make no representations or warranties whatsoever as to the accuracy, completeness, or suitability for any purpose of the Content. Any opinions and views expressed in this publication are the opinions and views of the authors, and are not the views of or endorsed by Taylor \& Francis. The accuracy of the Content should not be relied upon and should be independently verified with primary sources of information. Taylor and Francis shall not be liable for any losses, actions, claims, proceedings, demands, costs, expenses, damages, and other liabilities whatsoever or howsoever caused arising directly or indirectly in connection with, in relation to or arising out of the use of the Content.

This article may be used for research, teaching, and private study purposes. Any substantial or systematic reproduction, redistribution, reselling, loan, sub-licensing, systematic supply, or distribution in any form to anyone is 
expressly forbidden. Terms $\&$ Conditions of access and use can be found at http://www.tandfonline.com/page/terms-and-conditions 


\section{DR. HOWITT'S DEFENCE OF GROUP- MARRIAGE.}

BY N. W. THOMAs,

ONE of the main difficulties of controversy is to get an intelligible reply to a criticism, and this is nowhere more true than in the sphere of anthropology. Especially in the field of social organisation are misunderstandings frequent; at the root of most of them lie "terminological inexactitudes." In dealing with totemism some authorities use all terms interchangeably; the terminology of marriage is equally vague, and the term "group-marriage" is applied to two forms of sexual relations which should be kept entirely distinct, if logical fallacies and complete failure to deal with the real points at issue are to be avoided. In his recent communication, ${ }^{1}$ Dr. Howitt, in a reply to $\mathrm{Mr}$. Lang, treats pirrauru marriage as identical with groupmarriage; he speaks of tippa-malku marriage as an encroachment on the pirraurs group right; and finally asserts the former existence of group-marriage wherever the classificatory system of relationship is in use. The classificatory system, however, is not more closely connected with the pirrauru system than with tippa-malku marriage, and the validity of Dr. Howitt's identification of the pirrause relation with the kind of group-marriage for whose former existence he argues may justly be challenged.

In certain tribes of the Lake Eyre district-the Dieri, the Kurnandaburi, and the Urabunna-individual marriage,

${ }^{1}$ Fialklore, xvil. 174 sq. 


\section{Dr. Howitts Defence of Group-Marriage. 295}

known in the former tribe as tippa-malku marriage, but nameless, so far as we know, in the two latter-is combined with modified polygamy. In his work on the tribes of South-East Australia, Dr. Howitt asserts, in the most unqualified manner, that a woman must enter into the tippa-malku relation before she can receive a pirrauru or accessory spouse. This statement he qualifies in his reply to Mr. Lang, but without explaining on what grounds he does so. It would be interesting to learn whether more recent observations have thrown doubt on the information which he published in 1904, for, unless my information is misleading, the social organisation of the Dieri has been decadent for the last thirty years, and we cannot lay much stress on modern observations. So far as I know, the earlier information, gathered by an inaccurate observer, Mr. Gason, does not throw any doubt on the priority of the tippa-malku relation. Unless, therefore, Dr. Howitt relies on very recent information, I am unable to find any basis, and in no case any substantial basis, for the modification of his phraseology.

The pirrauru relationship, which is properly speaking modified polygamy, is established by a special ceremony performed by the head or heads of the totem-kin or kins concerned (I do not understand why Dr. Howitt suggests that only one totem-kin may be concerned; under the exogamic rule the pirrauru spouses must obviously be of different totems) $;^{8}$ in the case of the woman it has always been supposed, up to the time of Dr. Howitt's recent communication, that the tippa-malku relation necessarily precedes the pirrauru relation; for the man a tippa-malku spouse is not necessary before he enters into pirrauru relations with a woman. The essential feature of the pirrauru relation is that certain men and women have

1 Pp. 177-179, N.T.S.E.A.

a Gregory, Dead Heart, p. 192.

- Many other questions arise in connection with Dr. Howitt's account of pirrawrm. With these I deal in a work now in the press 


\section{Dr. Howitt's Defence of Group-Marriage.}

sexual relations with each other, firstly, at times of tribal ceremonial; secondly, when the tippa-malku spouse of the woman permits it; and thirdly, in the absence of that spouse.

Both tippa-malku and pirraume relationships receive tribal recognition and sanction; all who enter into either of these relationships must stand to one another in the relation termed by the Dieri noa, which may be translated "marriageable" But not all who are noa to each other become cither tippa-malku or pirrauru to each other. The group-marriage, whose prior existence is asserted by Dr. Howitt, not only for the whole of Australia, but also for all countries in which the classificatory system is in use, cannot, with any propriety, be termed marriage at all ; its proper name is "modified promiscuity." According to this view, all the people who stood in the noa relation to each other were de jure and de facto husbands and wives. At the present day noo undoubtedly means no more than "marriageable," and nothing which Dr. Howitt has put forward in his reply to Mr. Lang goes to show that it ever meant anything else.

In Europe we use the descriptive system of relationship; it is essentially based on consanguinity; if two persons are stated to stand in the relation of father and son, we assert a physiological fact. The classificatory system, on the other hand, is essentially a legal system; the term which a boy applies to his father, whose identity is often no more in doubt among these peoples than it is among peoples using the descriptive system, he also applies to a number of other men, any of whom was eligible to marry his mother; similarly he applies to his mother the same term that he applies to a number of women, all of whom were eligible spouses for his father; it is sufficiently clear that the identity of the real mother is not in doubt.

Some tribes, of whom the Dieri is one, apply a special 


\section{Dr. Howitt's Defence of Group-Marriage. 297}

term to the own father or the primary husband; others have a distinctive name for the real mother. But the presence or absence of the special term does not mean that the relation of parents and children differs in the tribes in question. In the same way there are tribes which recognise the existence of sisters or cousins in blood, whose position differs from that of the other members of the tribe who stand in the same (legal) relationship to their brother or cousin. From our point of view, group-terms are not, and never can have been, adequate expressions of certain relationships, such as mother and child, but it cannot be argued that the absence of terms to express those relationships means that the relationship did not originally exist. With these introductory remarks, I pass to a consideration of Dr. Howitt's remarks in detail.

Dr. Howitt gives a long list of "marital terms." By this he means the terms which are applied to each other by persons eligible to marry. These terms, with the exception of pirrauru and piraungaru, of which I have already spoken, correspond to the Dieri term noa; in some cases they differ according to the sex of the speaker; in others, as among the Dieri, they are the same for both sexes. Now, in the diagrams on page 182 , and in the text of the following page, Dr. Howitt asserts a correspondence in meaning and use between pirrauru (Dieri) and maian-bra (Kurnai), and on this alleged correspondence turns the whole of his argument for group-marriage. But in point of fact, unfortunately for Dr. Howitt, no such correspondence exists. Maian-bra corresponds not to pirrauru, but to noa; they do not imply sexual relations between the parties who apply these terms to each other; and they do not mean that any ceremony has been performed to constitute the relationship between the man and woman. In what sense then does Dr. Howitt assert the parallelism of the two sets of terms? 


\section{Dr. Howitt's Defence of Group-Marriage.}

Not content with asserting a non-existent equivalence, Dr. Howitt, by choosing the Kurnai as the tribe with which to compare the Dieri, has invited reference to a difficulty in the way of interpreting noa as a survival of group-marriage. On p. 170 of his Native Tribes he says of the "fraternal terms" of the Kurnai that they are "far wider than those of the Dieri, and appear to point to a time prior to the making of those restrictions which necessitated the use of (different) terms to distinguish between a man's own children and those of his sister ... ." in other words, that they point to a period of absolute promiscuity within the generation, to a time when brother and sister marriage was universal and individual marriage unknown. This inference, however, Dr. Howitt refuses to draw; he will not admit that the Kurnai ever had more than "group-marriage," i.e modified promiscuity. He argues that maian-bra is a relic of group-marriage; but if the philological basis, which is all that this argument possesses, is adequate, we are entitled to ask why Dr. Howitt refuses to draw the appropriate conclusion from the fraternal terms. Either the philological argument is reliable or it is not. If it is not, the theory of group-marriage (modified promiscuity) finds no support in any of the relationship terms adduced by Dr. Howitt; it rests at best on a fancied identity of the pirraure and the noa relationships. If, on the other hand, the philological argument holds good, why does Dr. Howitt refuse to pursue it to its logical conclusion? It would be especially interesting to hear the grounds on which he thinks these fraternal terms cannot be regarded as a legacy of the age of the Undivided Commune.

Dr. Howitt says on p. 185, "marriage between them as pirrauru or piraungaru is group-marriage [i.e polygamy] and is defined by the terms of relationship. Such being the case, these must have originated when group-marriage [i.e. modified promiscuity] existed." These statements will not bear examination. 


\section{Dr. Howitts Defence of Group-Marriage. 299}

I have already pointed out that to use the term "groupmarriage" of pirrauru, is confusing. Pirrauru is (1) not a necessary relation in any single case; $(2)$ is entered upon by a definite ceremony; (3) is entered upon by individuals, no more and no less than the tippa-malku relation; and (4) is for the woman, so far as we know, subsequent to tippamalku.

The other group-marriage (modified promiscuity) is (I) held to be a necessary relationship, exactly as is noa; (2) it is consequently entered into by no ceremony, collective or (3) otherwise; and (4) is of necessity a relation antecedent to all marital relationships. In a sense, of course, the people standing in the relation of pirraurs are a group; the relationship is a combination of polyandry and polygyny, and if Dr. Howitt chooses to say that either or both of the latter are also group-marriage, his assertion is just as true as it is of pirrauru; but the group-marriage thus asserted to exist has in neither case any relation to the assumed modified promiscuity to which the name of group-marriage is also applied.

In saying that pirrauru is "defined by the terms of relationship," Dr. Howitt seems to mean no more than that the pirraurus must also be noa to each other, exactly as must the tippa-malku husband and wife. But any inference which can be drawn from the one case can also be drawn from the other. That a man may marry only such women as are marriageable proves no more in the case of pirrauru than it does in the case of polygyny, or of individual marriage, tippa-malku or otherwise.

By a singular piece of reasoning Dr. Howitt goes on to infer that group-marriage must have existed when the group-terms were invented. This conclusion does not follow from his argument as to pirrauru, for I have shown how far pirrauru is from resembling the assumed groupmarriage. In fact, Dr. Howitt himself admits as much in his next paragraph (p. 185), where he speaks of his 


\section{Dr. Howitts Defence of Group-Marriage.}

assertion of the prior existence of group-marriage as an assumption; he devotes eleven pages to matter connected with this assumption, but apparently recognises that at the end it remains an assumption still. Except in so far as the assertion of the identity of pirrauru and group-marriage (= modified promiscuity), and of the validity of the philological argument for group-marriage, can be reckoned as serious attempts at proof of their position, it may truly be said that believers in group-marriage have confined themselves to affirming that their view must be right. They never deign to consider in detail the arguments of the other side; at most they pass them over with the remark that the man on the spot understands all this much better than we can in England, quite ignoring the fact that, if they are thought fallible, it is erroneous logic, not malobservation, which is laid at their door.

As to group-marriage being a necessary inference from the use of group terms, we may ask : (1) Has Dr. Howitt or any one else ever produced any direct evidence that people in the noa relation were ever de facto and de jure in the position of husbands and wives to each other in any way in which they are not at the present time? (2) Has Dr. Howitt or any other believer in group-marriage ever taken any notice of the argument that noa means "marriageable" not "married"? (3) Has Dr. Howitt or anyone else ever replied in detail to any of the objections ${ }^{1}$ which have been urged against the group-marriage theory? If so, will he oblige me by giving the reference?

In asserting the validity of the argument from terminology, Dr. Howitt strangely overlooks more than one fact. (I) He has himself asserted, apropos of the Kurnai, that terminology is an uncertain basis; (2) an alternative rendering of noa ("marriageable," instead of "married ") has been proposed; (3) if we conclude from the absence of terms for father and other individual relationships that the

${ }^{1}$ Lang, Secrat of the Totem, Pp. 38, 39. 


\section{Dr. Howitt's Defence of Group-Marriage. 301}

father did not exist as an individual, we must also conclude that there were group-mothers. Will Dr. Howitt accept this view? Will he admit that group-motherhood as well as group-marriage existed ? If not, will he tell us wherein lies the essential difference between the cases?

On p. I 86 Messrs. Spencer and Gillen are cited to show that pirrauru is not an abnormal development. In reply to this I will point out (I) that in the Lake Eyre tribes alone does a name exist for polygamy; all the other tribes cited by Dr. Howitt have terms corresponding to noa; none has anything corresponding to pirrauru, dilpa malli, and piraungaru. That alone is conclusive evidence of differential evolution among the Lake Eyre tribes; (2) in two of these three cases there is a special ceremony of allotment which cannot have existed if modified promiscuity were ever the practice. If the kandri ceremony occurs elsewhere, it is unfortunate that Dr. Howitt has not discovered it. If it does not, we have additional evidence that pirrauru is something out of the normal course.

Dr. Howitt holds (p. 187) that the jus primae roctis is also group-marriage. If I am right in supposing that a woman must be tippa-malku before she is pirrauru, this constitutes a marked difference between the Dieri custom and the Kurnai practice in question. Dr. Howitt does not, it is true, tell us whether the right of access of the brogan is exercised before or after that of the husband. If the former, as is usually the case, the practice cannot be put on a par with the pirrauru relation, which it resembles in no single important particular, and, as Mr. Lang has pointed out, the custom is not marriage at all. It is a mere guess that it has anything to do with the supposed state of group-marriage. Dr. Howitt twits Mr. Lang with guessing, and with not observing that tippa-malku is an individual relationship. If he will look at p. 53 of Mr. Lang's Secret of the Totem, he will see that 


\section{Dr. Howitt's Defence of Group-Marriage.}

the latter charge is erroneous. With far more truth Mr. Lang can retort that Dr. Howitt has overlooked the fact that although motherhood cannot be a group-relationship, the Australian often has no individual term which he applies to his own mother. It is conceivable that none of the group-terms on which Dr. Howitt lays such stress bears the meaning he puts upon them; in the case of "mother" it is inconceivable that his interpretation should be right. If, therefore, anyone has overlooked the important point of individual terms and relationships, it is Dr. Howith, not Mr. Lang. On p. 184 Dr. Howitt asserts " that the aboriginal terms (of relationship) include relationships as understood by us, and at the same time include persons who under the universal conditions of the Australian tribes are considered, for instance, to be 'fathers' or ' sons,' etc., as the case may be."

So far as I know it has never been denied that the aboriginal terms include relationships as understood by us; Mr. Lang has certainly never denied it. What he has done is to deny that the aboriginal terms can properly be translated by our terms. In reply to this Dr. Howitt asserts that all persons embraced under the term which includes our "father," are by the Australians regarded as fathers. Let us examine this statement in detail.

Fatherhood in our sense is a consanguineous relation; it expresses a physiological fact. Does Dr. Howitt assert that the Australian tribes mean this when they speak of a "father"? If so, what explanation does he offer of the Arunta denial of fatherhood in our sense? So far as I can see, the Arunta deny that anyone is a father in our sense. If so, in what sense can Dr. Howitt assert that they regard all men of a certain tribal status as fathers of a given child?

If Dr. Howitt asserts physiological fatherhood to be the underlying idea, does he assert the same of the term which includes "mother" in our sense? If he does, it is 


\section{Dr. Howitt's Defence of Group-Marriage. 303}

clear that motherhood for him means something very different from what it usually means. If he does not, and if by "father" he does not mean father in our sense, what is the point of his reply to Mr. Lang's objection, namely, that in using the term "father" Dr. Howitt is making use of a word which includes but does not denote the relationship as understood by us ?

Dr. Howitt's position appears to be-that in order to make us in Europe understand the meaning of mungan, to take his own example, he is obliged to tell us that it means father, whereas it does not mean anything of the sort. But that is precisely what Mr. Lang argued in this passage just quoted. If Dr. Howitt does not mean that, if he means that the term father was originally applied to a number of men because the real father could not be distinguished, will he say if he is ready to draw the same inference from the use of a group-term for mother? If he is not, what differentiates these two cases?

This brings me to a point in connection with which I may emphasise my previous contention that first-hand knowledge of the natives is no panacea for erroneous reasoning. Dr. Howitt cites against Mr. Lang the Dieri use of different terms for the primary and secondary spouses.

If this case proves anything, it proves that ngaperi does not mean father, for the terms are applied in the same way whether the primary or the secondary spouse is the real father. Ngaperi clearly does not mean father in our sense, but refers to status in the family, if Dr. Howitt's statement of the case is correct. It seems, however, that ngaperi is applied to all the brothers, own or tribal, of the primary spouse; if this is so, the term ngaperi waka has nothing to do with the pirrauru relationship at all; or have the Dieri yet another term for those who are not, but might legally be, pirrauru to the mother? However that may be, out of Dr. Howitt's own mouth I am able to quote words 


\section{Dr. Howitt's Defence of Group-Marmage.}

which show that ngaperi and ngaperi waka do not refer to physiological fatherhood. Yet Dr. Howitt cites the distinction as parallel to the Kurnai distinction between the "actual" and "nominal" husbands of a woman; in other words, he makes two cases parallel, though in one of them the terms refer to the status within the family, both ngaperi being possible fathers, in our sense, of the child, whereas in the other case the difference in terminology means that the murgan is the husband of the child's mother, while the breppa mungan is merely a man of the same tribal status who has no marital rights over the mother. Thus Dr. Howitt has been guilty of a grave confusion in his statement of the case against Mr. Lang's view.

But putting this aside-and I have cited it merely as an example of the errors from which first-hand knowledge will not save one-What does Dr. Howitt's contention at this point amount to? He admits that thundung and the corresponding Kurnai terms include all men of a certain tribal status, and the legitimate inference from this, if the philological argument is trustworthy, is that we have to do with an Undivided Commune, though, as we have seen, Dr. Howitt shrinks from this conclusion. Dr. Howitt himself admits that tribal status and not relationship, as we understand it, is expressed by these terms; yet although he declines to interpret the Kurnai terms in the same way as those of the other tribes, he insists that his interpretation of the terms of these other tribes is the only possible one; that anyone who declines, as does Mr. Lang, to accept this interpretation, is a mere theorist, an ethnologist of the study, who shows his ignorance at every turn and yet will not take the opinions of first-hand observers. If Dr. Howitt may decline to draw the logical inference from the Kurnai fraternal terms, why may not Mr. Lang decline to draw from the terms of the other tribes the inference which he regards as illogical? 


\section{Dr. Howites Defence of Group-Marriage. 305}

Perhaps the most singular thing about Dr. Howitt's argument at this point ${ }^{1}$ is that he nowhere puts forward facts, or correct statements as to present-day facts, which are not fully in accord with Mr. Lang's contention. Mr. Lang says, for example, that the terms of relationship now denote tribal status; Dr Howitt supports this by arguing that the term for father means "nominal father" in every case but one. I cannot therefore conceive why Dr. Howitt charges Mr. Lang with guessing at the meaning of the terms. Mr. Lang is also accused of guessing at their origin; I am not sure to what words of Mr. Lang's allusion is here made by Dr. Howitt ; but whatever they are, the view put forward is not inconceivable; but, as I have shown above, Dr. Howitt's view is inconceivable, if we apply it to the term which he would presumably translate into English as group-mother. Primd facie, therefore, Dr. Howitt is no less guilty of guessing; and his guesses are contradicted by common knowledge, while Mr. Lang's will bear examination.

A few lines above this ${ }^{2}$ Dr. Howitt asks Mr. Lang to look at the Dieri terms, and says, "he will see their present meaning and that they are applied ... to individuals ... living under pirrauru." If this statement were correct, the Dieri would be living, not under pirrauru, but under modified promiscuity ; for this passage clearly suggests that all who are noa to each other are also pirrauru. What Dr. Howitt actually means, however, is that some people who are noa are also pirrauru-a very different thing. In the following sentence he asserts that the group terms of the other tribes mentioned by him denote not individual but pirrauru marriage. But the group terms of other tribes as little denote pirraurs among them as does noa among the Dieri; up to the present Dr. Howitt has not even produced a pirraurupractising tribe outside the Dieri nation. If Dr. Howitt's

$$
{ }^{1} \text { Pp. 183-185. }
$$

2. 184 


\section{Dr. Howites Defence of Group-Marrage.}

statements were correct, Mr. Lang would certainly need to modify the passage quoted by his critic; in point of fact Dr. Howitt has merely shown that first-hand knowledge no more confers immunity against errors of fact than it does against errors in logic.

Put briefly, Dr. Howitt's points are as follows :

(1) Pirrauru is a survival of group-marriage. This is arguable, but far from proven, even if it be shown on other grounds that group-marriage ever existed.

(2) The term pirrauru is equivalent to the group terms of other tribes, pirrauri denotes a group relationship, and consequently the group terms of other tribes must do so too. I have shown (a) that pirrauru is not equivalent to the group-terms of other tribes and (b) that it is not a grouprelationship in the same sense as group-marriage.

(3) Group-terms necessarily imply a former group relationship. I have shown that (a) Dr. Howitt declines to accept the philological argument where it does not fit in with his views; $(b)$ if the group-father is accepted on this ground, we must likewise accept the group-mother, and up to the present no believer in group-marriage has had the courage to do more than assert that the argument is unworthy of notice.

(4) If individual relationships were known, individual terms of relationship would have survived. But the individual mother was of necessity known; yet no term for the individual mother is found in most tribes; hence it is not necessary that individual terms should have been known or have survived.

Anthropologists have every reason to be grateful to Dr. Howitt for his work in the field; a great part of our knowledge of Australian tribes is due to him. But he overlooks the fact that field-work and interpretation are two entirely different spheres of activity. If the field-work has been well and truly done, if the results have been accurately set forth, the work of synthesis must be begun; 
Dr. Howritt's Defence of Group-Marriage. 307

and as a rule it falls to the lot of others to deal with the materials accumulated by the field-anthropologist. If the latter is to make good his views as to origins against the anthropologist of the study, it must be, not by the assertion that the man on the spot can alone judge of these things, but by the more skilful use of his materials, that he must gain the day. How far Dr. Howitt has, in fact, done so, is a question on which the present controversy provides some materials for judgment.

N. W. Thomas. 